\title{
Immunoelectrophoretic Separation of Spiroplasma Antigens
}

\author{
By DAVID B. ARCHER* AND ROD TOWNSEND \\ John Innes Institute, Colney Lane, Norwich NR4 7UH
}

(Received 21 July 1980)

\begin{abstract}
Antigens from a number of spiroplasmas were solubilized in the neutral detergent Lubrol PX and compared by crossed immunoelectrophoresis. Samples were also run in tandem with the type species Spiroplasma citri, continuity of immunoprecipitin rockets indicating antigenic identity and serological relatedness of spiroplasmas. It was concluded that corn stunt spiroplasmas, the honeybee (BC3) spiroplasma and the tick $(277 \mathrm{~F})$ spiroplasma were related serologically to $S$. citri but some flower isolates and the tick (SMCA) spiroplasma showed no obvious relationship. The serological relatedness of $S$. citri and the honeybee (BC3) spiroplasma was investigated in detail. These two spiroplasmas each contain a major membrane protein which differ slightly in molecular weight. The two proteins were purified under identical conditions and used to raise monospecific antisera. Using the sera obtained in this way with a modified immunoelectrophoretic system having sodium dodecyl sulphatepolyacrylamide gel electrophoresis as the first dimension separation, it was shown that the major membrane proteins of $S$. citri and the honeybee (BC3) spiroplasma are antigenically dissimilar. We suggest that spiralin, the major membrane protein of $S$. citri, and the major membrane protein of the honeybee (BC3) spiroplasma are dominant cell surface antigens, so that while these two spiroplasmas are known to be very similar, serological tests involving comparison of cell surface antigens indicate less relationship.
\end{abstract}

\section{INTRODUCTION}

Relatedness of spiroplasmas has been estimated by many techniques, and serology has played a major part in formulating classification schemes within the family Spiroplasmataceae (Order Mycoplasmatales, Class Mollicutes). At least four serological groups are recognized (Davis et al., 1979; Williamson et al., 1979). The Spiroplasma citri group includes sub-groups of corn stunt spiroplasmas, some honeybee spiroplasmas, including strain BC3, and the tick $(277 \mathrm{~F})$ spiroplasma.

Serological typing gives a technically simple approximation to genotypic homology, but different serological tests indicate different levels of relatedness between spiroplasmas. Spiroplasma citri and BC3 have a $65 \%$ DNA homology (Junca et al., 1980) and very similar protein banding patterns on sodium dodecyl sulphate (SDS)-polyacrylamide gels (Archer \& Best, 1980). However, serological tests which recognize cell surface antigens on intact cells, such as organism deformation (Williamson et al., 1978, 1979) and enzyme-linked immunosorbent assay (Archer \& Best, 1980), indicate a much lower level of relatedness between these organisms. Crossed immunoelectrophoresis affords comparison of individual protein antigens and we have used this technique to determine the distribution of protein antigens of the type species $S$. citri in other spiroplasmas.

The major membrane protein of $S$. citri, spiralin (Wróblewski et al., 1977), spans the membrane (Wróblewski, 1978) and strain BC3 contains a major membrane protein of slightly higher molecular weight (Archer \& Best, 1980). We have purified spiralin and the major membrane protein of BC3 by agarose suspension electrophoresis (Hjertén, 1963) and 
present evidence that these two proteins have some similar properties but are serologically dissimilar.

\section{METHODS}

Spiroplasmas and growth conditions. The spiroplasmas used in this work and their growth conditions have been described previously (Archer \& Best, 1980).

Antisera. Antisera to spiroplasmas were raised in rabbits using either washed cells or SDS-solubilized cells as antigens (Archer \& Best, 1980). Homologous deformation titres (Williamson et al., 1978) were between 10000 and 15000 .

Monospecific antisera against the major membrane proteins of $S$. citri and strain BC3 were raised in rabbits using purified proteins as the antigens. Spiralin (from S. citri) and its supposed counterpart in BC3 were purified under identical conditions by agarose suspension electrophoresis (Hjertén, 1963) according to Wróblewski et al. (1977). The purity of the preparations was determined on SDS-polyacrylamide ( $12 \%$, w/v, acrylamide) tube gels (Laemmli \& Favre, 1973). Monospecific antiserum was raised against the major membrane protein of BC3 solubilized in SDS: the region of polyacrylamide gel containing the protein band (after purification by agarose suspension electrophoresis) was excised and crushed, forming the antigen. The use of Freund's incomplete adjuvant, and the injection and bleeding schedules were as described by Archer \& Best (1980) except that approximately $1 \mathrm{mg}$ purified protein constituted the total challenge to the rabbit. Monospecific antiserum against purified spiralin (from S. citri strain C 189; ATCC 27665) was generously provided by H. Wróblewski.

Immunoelectrophoresis. Crossed immunoelectrophoresis in agarose $(1 \%, w / v)$ gels was performed as described by Archer \& Best (1980) except that Lubrol PX (Sigma) was used instead of Triton X-100.

Two-dimensional immunoelectrophoresis, using proteins separated through polyacrylamide gel slabs in the presence of SDS as the first dimension, was also used. The method of Chua \& Blomberg (1979) was used with some modification. The first dimension was run according to Laemmli \& Favre (1973) on slab gels and the tracks were then excised and equilibrated in $50 \mathrm{~mm}$-Tris/citric acid, $\mathrm{pH} 8.6$ (TC buffer) containing $0.5 \%(\mathrm{w} / \mathrm{v}$ ) sodium deoxycholate. Equilibration with occasional shaking was for at least $1 \mathrm{~h}$ at $20^{\circ} \mathrm{C}$ but up to $48 \mathrm{~h}$ at $4{ }^{\circ} \mathrm{C}$ was satisfactory. For the second dimension electrophoresis in agarose, the cathodal, intermediate and antibodycontaining agarose gels of Chua \& Blomberg (1979) were retained except that $0.5 \%(w / v)$ sodium deoxycholate was used throughout the gel and no neutral detergent was present. The composite agarose $11 \%(\mathrm{w} / \mathrm{v})$ low electroendosmosis agarose (Miles Laboratories, Stoke Poges) in TC bufferl/polyacrylamide gel slabs were run at $2.5 \mathrm{~V} \mathrm{~cm}^{-1}$ for $18 \mathrm{~h}$ at $15^{\circ} \mathrm{C}$. The antiserum content in the gels varied between experiments but was in the range 2 to $10 \%(\mathrm{v} / \mathrm{v})$. The agarose gel was stained as described by Archer \& Best (1980) and comparison was then made with a stained (Fairbanks et al., 1971) polyacrylamide first dimension gel which had not been run in the second dimension.

Cytochemical localization of spiralin. Spiroplasmas were fixed in glutaraldehyde $(4 \%, w / v)$ for $1 \mathrm{~h}$ at $20^{\circ} \mathrm{C}$. They were then sedimented and washed twice in basal medium lacking serum (Archer \& Best, 1980) and finally resuspended in basal medium. Monospecific antiserum against either spiralin or the purified major membrane protein of $\mathrm{BC} 3$ was then added to the spiroplasma suspension (approximately $10^{9} \mathrm{cells} \mathrm{m}^{-1}$ ) to a final concentration of $5 \%\left(\mathrm{v} / \mathrm{v}\right.$ ). After $30 \mathrm{~min}$ at $20^{\circ} \mathrm{C}$ ferritin-conjugated anti-rabbit IgG (goat; $2 \%, \mathrm{v} / \mathrm{v}$; Miles-Yeda, Israel) was added. After a further $30 \mathrm{~min}$ at $20^{\circ} \mathrm{C}$, the spiroplasmas were sedimented and washed twice in basal medium. Samples of resuspended spiroplasmas on carbon-coated grids were examined unstained by electron microscopy.

\section{RESULTS \\ Crossed immunoelectrophoresis of Lubrol-solubilized antigens}

Crossed immunoelectrophoretograms of Lubrol-solubilized spiroplasma antigens with antiserum against $S$. citri are shown in Fig. 1. Figure $1(a)$ shows the homologous reaction with $S$. citri; heterologous reactions with BC3 (Fig. 1 b), corn stunt spiroplasma (Fig. $1 c$ ) and tick $(277 \mathrm{~F})$ spiroplasma (Fig. 1d) are also shown. No rockets were seen with tulip tree isolates SR-3, 23-6 or BNR-1, or with tick (SMCA) spiroplasma.

Tandem crossed immunoelectrophoretograms of pairs of spiroplasmas, all reacted with antiserum against $S$. citri, are shown in Fig. 2: BC3/S. citri (Fig. 2a); corn stunt spiroplasma/S. citri (Fig. 2b); 277F/S. citri (Fig. 2c); corn stunt spiroplasma/BC3 (Fig. $2 d$ ). Continuity of the precipitin line between immunoprecipitin rockets indicates antigen identity. 


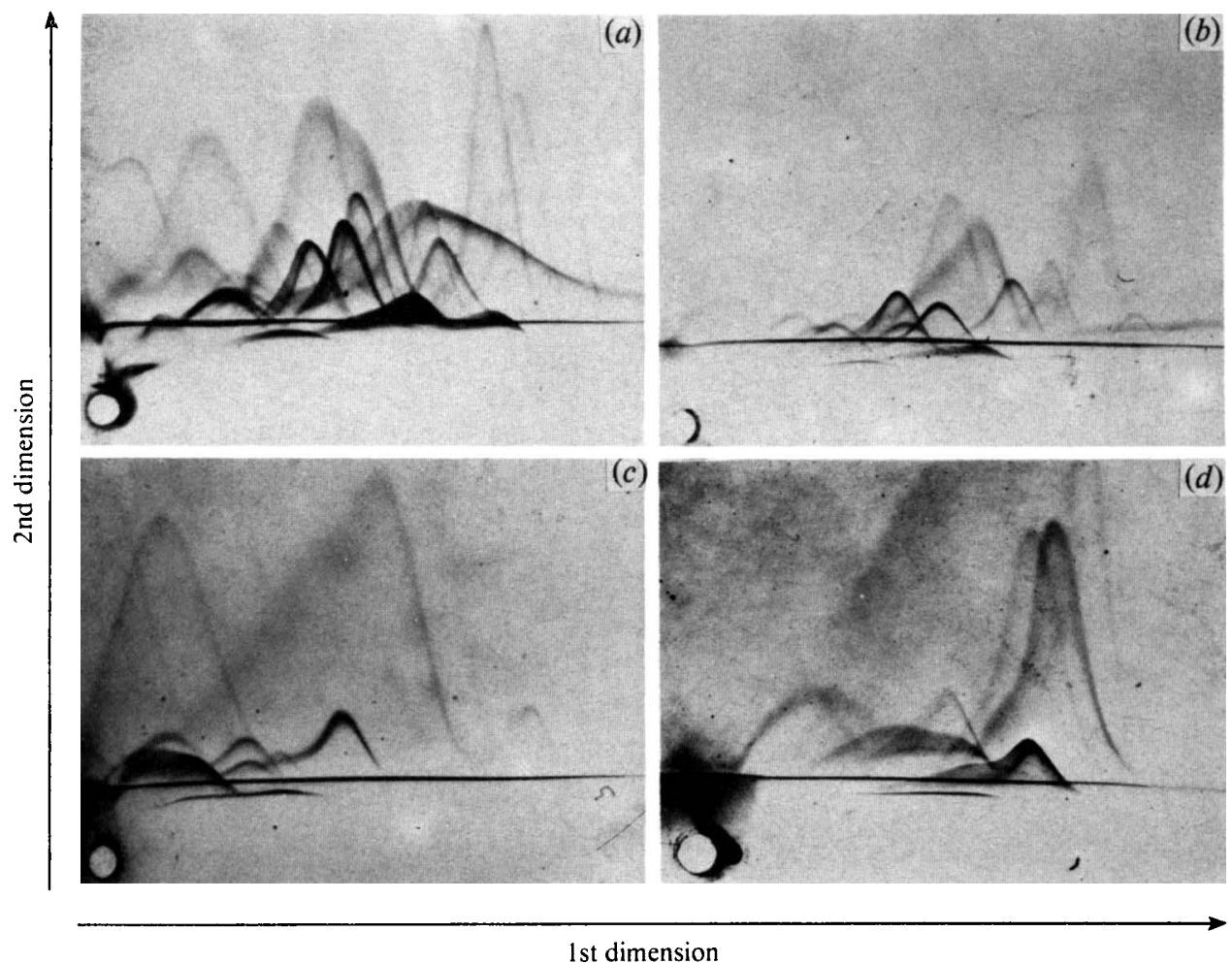

Fig. 1. Crossed immunoelectrophoresis in Lubrol PX. Crossed immunoelectrophoresis of Lubrol PX-solubilized spiroplasma antigens was carried out in agarose gels containing antiserum against $S$. citri in the second dimension. The antigens applied to the wells at the lower left of the gels were $S$. citri $(a)$, BC $3(b)$, corn stunt spiroplasma $(c)$ and tick $(277 \mathrm{~F})$ spiroplasma $(d)$.

Up to 30 rockets could be counted when $S$. citri was reacted with its homologous antiserum and approximately two-thirds of these formed fused rockets with BC3 antigens. Somewhat fewer fused rockets were seen with the corn stunt spiroplasma/S. citri tandem gel. Tick (277F) spiroplasma also showed antigenic proteins in common with $S$. citri but higher than normal amounts of antigen and antiserum were required for adequate staining of rockets formed between $277 \mathrm{~F}$ antigens and $S$. citri antiserum.

\section{Immunoelectrophoresis of SDS-solubilized proteins}

Figures 3, 4 and 5 are composites of the SDS-polyacrylamide gel pattern and the final immunoelectrophoretogram after staining. The polyacrylamide gel was loaded at the right-hand side as viewed, so that the molecular weights of the protein bands decrease from right to left.

Figure $3(a)$ shows $S$. citri proteins electrophoresed into a gel containing its homologous antiserum. As with all gels of this type, very few rockets were visible. This was not due to the antiserum failing to recognize SDS-denatured protein antigens because an antiserum raised against SDS-solubilized antigen gave an identical pattern. The proteins were not completely removed from the polyacrylamide gel but staining of bands (Fairbanks et al., 1971) was very faint after second dimension electrophoresis. The densely staining rocket in Fig. $3(a)$ (arrowed) corresponds to the major protein of $S$. citri and this was identified as spiralin by removal of this rocket with monospecific antiserum against spiralin (Fig. 4). Antiserum against BC3 did not produce the same densely staining rocket with $S$. citri proteins, although a diffusely staining rocket was clearly visible (Fig. $3 b$ ). Strain $\mathrm{BC} 3$ proteins produced some 


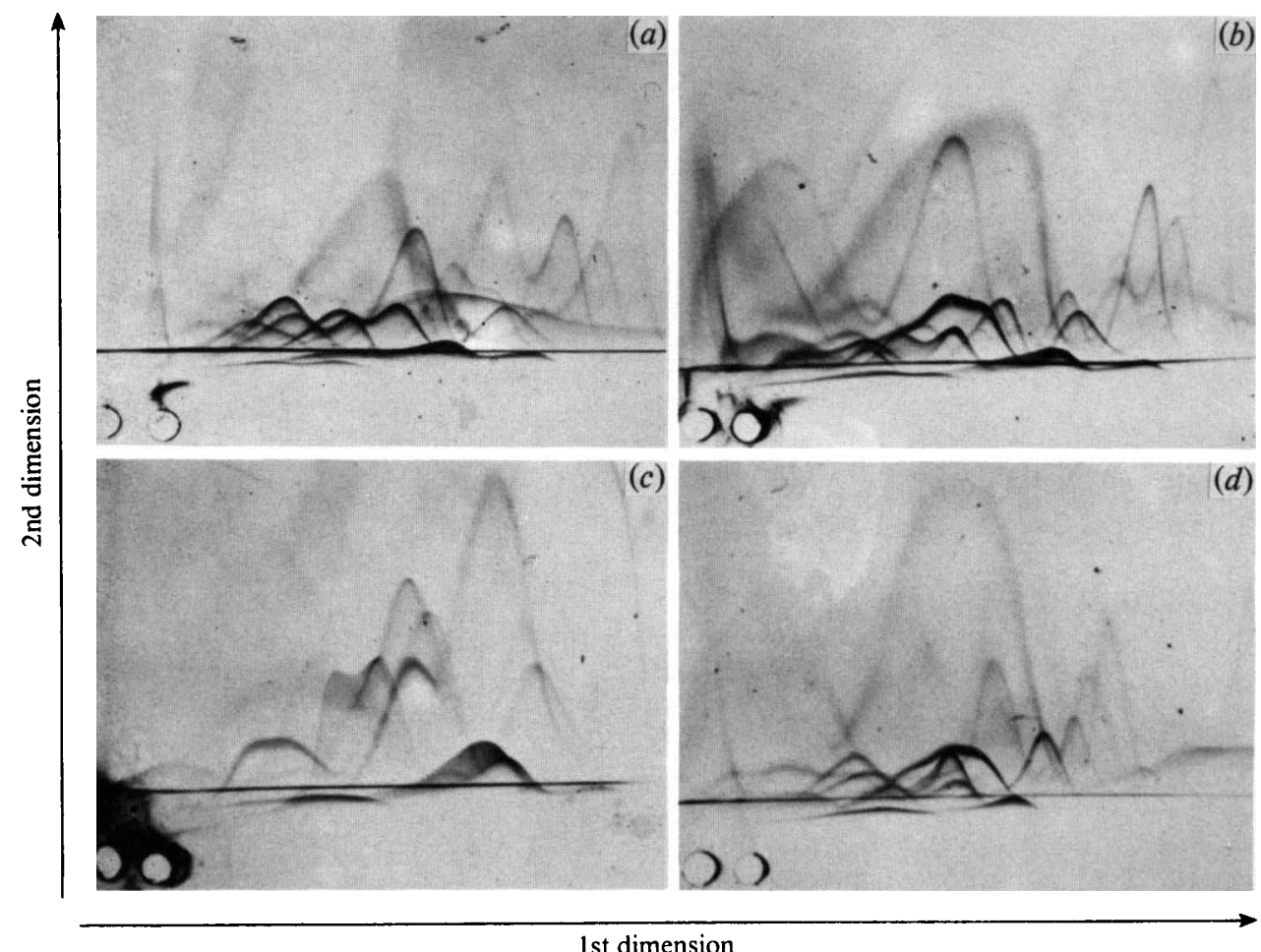

1st dimension

Fig. 2. Tandem crossed immunoelectrophoresis. Lubrol PX-solubilized spiroplasma antigens were electrophoresed in tandem with a different isolate. The second dimension gel contained antiserum against $S$. citri. The antigens applied to the left-hand and right-hand wells, respectively, were BC 3 and $S$. citri $(a)$, corn stunt spiroplasma and $S$. citri $(b)$, tick $(277 \mathrm{~F})$ spiroplasma and $S$. citri $($ c) and corn stunt spiroplasma and BC3 $(d)$.

rockets in gels containing antiserum to $S$. citri (Fig. $3 c$ ) but the densely staining rocket characteristic of spiralin was absent. Strain BC3 proteins produced a spiralin-type rocket with homologous antiserum and this was located over the major protein band of the first dimension polyacrylamide gel (Fig. $3 d$ ). In addition, a fainter rocket was formed which corresponded to a slightly lower molecular weight than the densely stained rocket. The molecular weight of the major BC3 protein was estimated as 25000 by comparison with molecular weight standards on SDS-polyacrylamide gels whereas spiralin from $S$. citri strain SP-A had an estimated molecular weight of 23000.

\section{Immunoelectrophoresis of purified proteins}

The proteins purified from $S$. citri and strain BC3 by agarose suspension electrophoresis were free from any other proteins with similar molecular weights although minor contaminating proteins of higher molecular weights were also present (Fig. 5). The protein purified from $S$. citri strain SP-A produced a densely stained rocket with antiserum against $S$. citri (Fig. 5a). An identical rocket was produced with monospecific antiserum against spiralin from $S$. citri strain C189, identifying the purified protein from strain SP-A as spiralin. Purified spiralin (from SP-A) produced no visible rocket with antiserum against BC3 or with monospecific antiserum against the purified major $\mathrm{BC} 3$ membrane protein.

The major protein purified from $\mathrm{BC} 3$ produced a densely staining rocket with its homologous monospecific antiserum and also with antiserum against BC3 (Fig. $5 b$ ). No rocket was seen with monospecific antiserum against $S$. citri spiralin. A very faint rocket was seen with antiserum against $S$. citri but this was so faint as to be missed on many gels, and it 


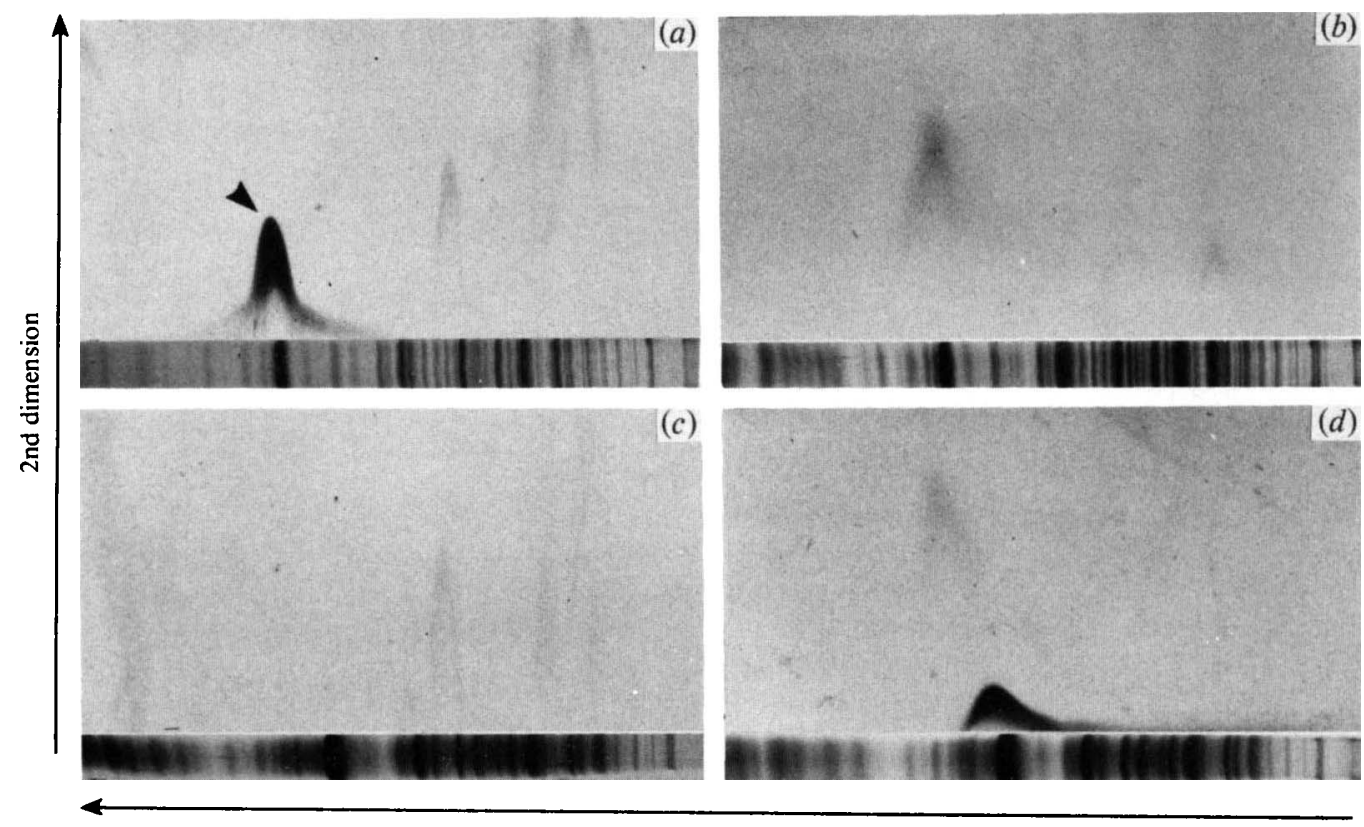

Ist dimension

Fig. 3. Immunoelectrophoresis of SDS-solubilized antigens. The lower gels were SDS-polyacrylamide gels, loaded at the right-hand side as viewed, containing proteins of $S$. citri $(a, b)$ and BC3 $(c, d)$. Agarose second dimension gels in deoxycholate contained antiserum against $S$. citri $(a, c)$ and BC3 $(b$, $d)$. The precipitin rocket due to spiralin is arrowed in $(a)$.

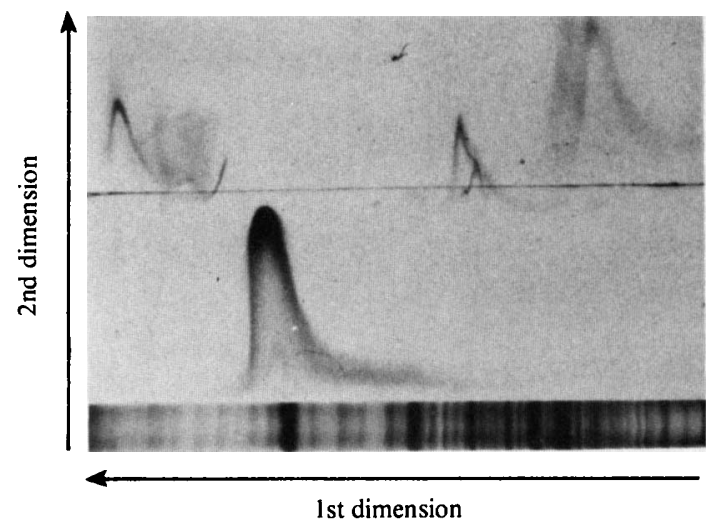

Fig. 4. Immunoelectrophoresis with intermediate gel. Immunoelectrophoresis of SDS-solubilized $S$. citri proteins was performed as in Fig. $3(a)$, except that an intermediate agarose gel containing monospecific antiserum against spiralin was inserted between the first dimension polyacrylamide gel and the agarose gel containing antiserum against $S$. citri.

is possible that in other heterologous reactions such faint rockets have also been missed although many variations of antigen/antiserum concentrations were routinely tried.

\section{Cytochemical localization of spiralin}

Ferritin granules were clearly associated with the BC3 spiroplasma after reaction with monospecific antiserum directed against the major membrane protein of $\mathrm{BC} 3$ and the ferritin-conjugated anti-rabbit IgG (Fig. $6 a$ ). Very few ferritin granules were seen associated 

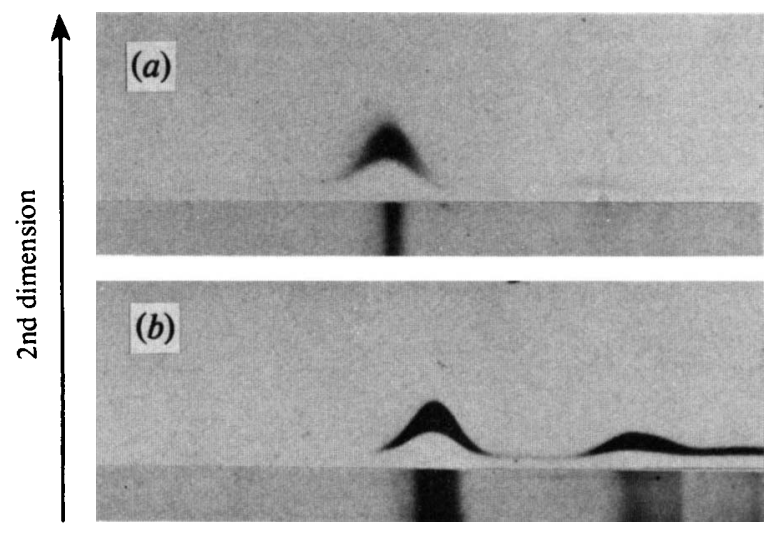

1st dimension

Fig. 5. Immunoelectrophoresis of purified proteins. The major membrane proteins of $S$. citri (spiralin) $(a)$ and $\mathrm{BC} 3(b)$ were purified by agarose suspension electrophoresis. The purified proteins were then subjected to immunoelectrophoresis using SDS-polyacrylamide gel electrophoresis as the first dimension. The second dimension agarose gels contained antiserum against $S$. citri $(a)$ and BC3 $(b)$.
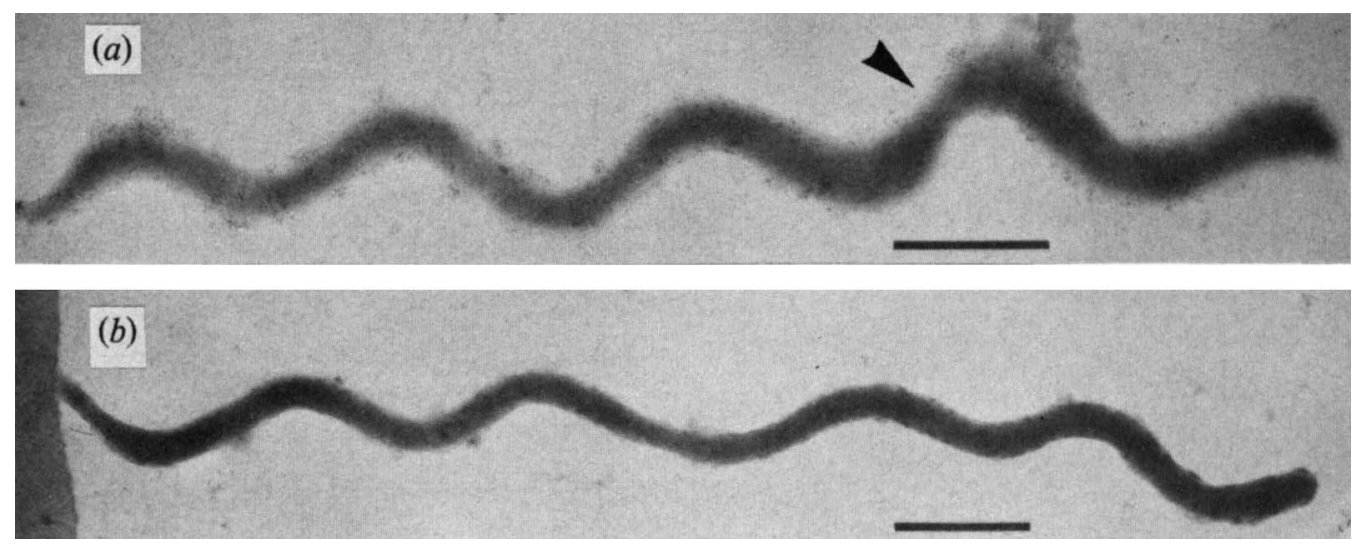

Fig. 6. Cytochemical localization of major membrane proteins. Fixed cells of BC3 $(a)$ and $S$. citri $(b)$ were mixed with monospecific antiserum against the purified major membrane protein of BC 3 . Ferritin-conjugated anti-rabbit IgG (goat) was then added and, after washing, unstained cells were examined in the electron microscope. A possible point of cell division is arrowed in $(a)$. The bar markers represent $500 \mathrm{~nm}$.

with $S$. citri (Fig. $6 b$ ) when reacted under identical conditions, and this amount of ferritin was little more than the background labelling seen in control experiments where monospecific antisera were omitted from the reaction sequence. Constriction along the length of a spiroplasma probably indicates a point of cell division and a clear example is arrowed in Fig. $6(a)$.

\section{DISCUSSION}

Comparison of spiroplasmas by crossed immunoelectrophoresis supports the inclusion of corn stunt spiroplasmas, the honeybee (BC3) spiroplasma and tick (277F) spiroplasma within the $S$. citri serological group. Recently, DNA pairing analysis has shown $S$. citri DNA to have $65 \%$ homology with DNA from BC3,53\% homology with corn stunt spiroplasma DNA and $4 \%$ homology with DNA from 277F (Junca et al., 1980). Crossed immunoelectro- 
phoresis detected no common antigens between $S$. citri and either tulip tree spiroplasmas BNR-1, SR-3 or 23-6 or tick (SMCA) spiroplasma. No DNA homology was detected between $S$. citri and these organisms either (Junca et al., 1980), although Christiansen et al. (1979) did report a $3 \%$ homology between DNAs from $S$. citri and SMCA, using the membrane filter technique (Denhardt, 1966). The number of immunoprecipitin rockets identified by crossed immunoelectrophoresis represents only a fraction (about 10\%) of the total number of polypeptides in spiroplasmas (Mouches et al., 1979). The resolution of two-dimensional gel electrophoresis (Mouches et al., 1979) is higher than that of crossed immunoelectrophoresis and while a number of the polypeptides may not elicit antibody formation in the rabbit it is unlikely that the number of rockets seen represents the total number of antigenic proteins. It is therefore possible that the tulip tree spiroplasmas and SMCA may have some relationship to $S$. citri. Highly conserved proteins common to all spiroplasmas might include those involved in cell shape determination or motility, and fibril protein (Townsend et al., 1980) is a suitable candidate for sequence conservation.

Spiralin, the major membrane protein of $S$. citri, is poorly solubilized from the $S$. citri membrane by neutral detergents (Wróblewski et al., 1977) although solubilization is better from spiralin/lecithin proteoliposomes (Wróblewski, 1979). Spiralin is, however, readily solubilized by the ionic detergents SDS and sodium deoxycholate and was identified immunologically in SDS-polyacrylamide gels. Spiralin retains antigenicity in SDS and it did not matter whether the antiserum used was raised against native or SDS-solubilized protein. The major membrane protein of $\mathrm{BC} 3$ and spiralin have similar solubility properties and could be purified under identical conditions. The two proteins may well have functional similarity but differ in molecular weight and in antigenicity.

Spiroplasma deformation (Williamson et al., 1979) and enzyme-linked immunosorbent assay (ELISA) (Archer \& Best, 1980; Tully et al., 1980) are two discriminating serological tests that detect cell surface antigens on intact cells, although ELISA is also applicable to broken cells. These two serological tests have indicated that the cell surface antigens of $S$. citri and BC3 show less relationship than would be expected from DNA homologies (Junca et al., 1980) and protein patterns on polyacrylamide gels (Archer \& Best, 1980). Spiralin is known to have exposed sites on the cell surface of $S$. citri (Wróblewski, 1978) and we have confirmed by cytochemical localization that the major membrane protein of $\mathrm{BC} 3$ also has exposed sites. The cytochemical work also confirmed the antigenic differences between spiralin and the major membrane protein of $\mathrm{BC} 3$. We conclude that spiralin, and the major membrane protein of $\mathrm{BC} 3$, are dominant cell surface antigens and the serological dissimilarity of the two proteins is reflected in the low level of cell surface serological relationship between S. citri and BC3.

We wish to express our gratitude to Jennifer P. Best for technical assistance and Kitty A. Plaskitt for electron microscopy.

This work was carried out under MAFF licence number HH 10912 issued under the Destructive Pests and Diseases of Plants Order 1965.

\section{REFERENCES}

Archer, D. B. \& Best, J. (1980). Serological relatedness of spiroplasmas estimated by enzymelinked immunosorbent assay and crossed immunoelectrophoresis. Journal of General Microbiology 119, 413-422.

Christiansen, C., AskaA, G., Freundt, E. A. \& Whiтсомв, R. F. (1979). Nucleic acid hybridization experiments with Spiroplasma citri and the corn stunt and suckling mouse cataract spiroplasmas. Current Microbiology 2, 323-326.

Chua, N.-H. \& Blomberg, F. (1979). Immuno- chemical studies of thylakoid membrane polypeptides from spinach and Chlamydomonas reinhardtii. A modified procedure for crossed immunoelectrophoresis of dodecyl sulfate protein complexes. Journal of Biological Chemistry 254, 215-223.

Davis, R. E., LeE, I.-M. \& Basciano, L. K. (1979). Spiroplasmas: serological grouping of strains associated with plants and insects. Canadian Journal of Microbiolog.' 25, 861-866.

Denhardt. D. T. (1966). A membrane filter tech- 
nique for the detection of complementary DNA. Biochemical and Biophysical Research Communications 23, 641-646.

Fairbanks, G., Steck, T. L. \& Wallach, D. F. H. (1971). Electrophoretic analysis of the major polypeptides of the human erythrocyte membrane. Biochemistry 10, 2606-2617.

HJERTÉn, S. (1963). Zone electrophoresis in columns of agarose suspensions. Journal of Chromatography, 12, 510-526.

Junca, P., Saillard, C., Tully, J., Garcia-Jurado, O., Degorce-Dumas, J.-R., MOUChes, C., Vignault, J.-C., Vogel, R., MCCOY, R., Whitcomb, R., Williamson, D., LATRILle, J. \& BovÉ, J. M. (1980). Caracterisation de spiroplasmes isolés d'insectes et de fleurs de France continentale, de Corse et du Maroc; proposition pour une classification de spiroplasmes. Compte rendu hebdomadaire des séances de l'Académie des sciences D290, 1209-1212.

Laemmli, U. K. \& Favre, M. (1973). Maturation of the head of bacteriophage T4. I. DNA packaging events. Journal of Molecular Biology 80, 575-599.

Mouches, C., Vignault, J. C., Tully, J. G., Whiтсомв, R. F. \& Bové, J. M. (1979). Characterization of spiroplasmas by one and two dimensional protein analysis on polyacrylamide gel slabs. Current Microbiology 2, 69-74.

Townsend, R., Archer, D. B. \& Plaskitt, K. A. (1980). Purification and preliminary characteriza- tion of spiroplasma fibrils. Journal of Bacteriology 142, 694-700.

Tully, J. G., Rose, D. L., Jurado, O. G., Vignault, J.-C., Saillard, C., Bové, J. M., McCoy, R. E. \& WILliamson, D. L. (1980). Serological analysis of a new group of spiroplasmas. Current Microbiology 3, 369-372.

Williamson, D. L., Whitcomb, R. F. \& Tully, J. G. (1978). The spiroplasma deformation test, a new serological method. Current Microbiology 1, 203207.

Williamson, D. L., Tully, J. G. \& Whitcomb, R. F. (1979). Serological relationships of spiroplasmas as shown by combined deformation and metabolism inhibition tests. International Journal of Systematic Bacteriologv 29, 345-351.

Wróblewskı, H. (1978). Spiralin: its topomolecular anatomy and its possible function in the Spiroplasma citri cell membrane. Zentralblatt für Bakteriologie, Parasitenkunde, Infektionskrankheiten und Hygiene (Abteilung I, Originale A) 241, $179-180$.

WróBlewsKi, H. (1979). Amphiphilic nature of spiralin, the major protein of the Spiroplasma citri membrane. Journal of Bacteriology 140, 738-741.

Wróblewski, H., Johansson, K.-E. \& HJertén, S. (1977). Purification and characterization of spiralin, the main protein of the Spiroplasma citri membrane. Biochimica et biophy'sica acta 465, 275-289. 